\title{
Identification of compounds that modulate retinol signaling using a cell-based qHTS assay
}

\author{
Yanling Chen ${ }^{1,3}$, Srilatha Sakamuru ${ }^{2}$, Ruili Huang ${ }^{2}$, David H. Reese ${ }^{1}$, Menghang Xia ${ }^{2}$
}

${ }^{1}$ Division of Molecular Biology, Office of Applied Research and Safety Assessment, Center for Food Safety and Applied Nutrition, U.S. Food and Drug Administration, Laurel, MD 20708

${ }^{2}$ National Center for Advancing Translational Sciences, National Institutes of Health, Bethesda, MD 20892

${ }^{3}$ Correspondence should be addressed to: Y. Chen, U.S. FDA, 8301 Muirkirk Rd, Laurel, MD 20708; Phone: 240-402-3394; Fax: 301-210-7976; Email: yanling.chen@fda.hhs.gov 


\section{Introduction}

Retinol (vitamin A) and its chemical analogs (retinoids ${ }^{1}$ ) are involved in the regulation of diverse biological processes including cell growth, vision, reproduction, immune response and embryonic development ${ }^{2 ; 3 ; 4 ; 5 ; 6 ; 7}$. In vertebrates, dietary retinol is metabolized to various retinoids. Among these, atRA is the predominant natural metabolite and also the major biologically active form of retinol ${ }^{8}$. atRA is an activating ligand for the retinoic acid receptors $(\text { RARs })^{9 ; 10}$ that form heterodimers with the retinoid X receptors (RXRs) ${ }^{11}$ on the retinoic acid response element (RARE) ${ }^{12 ; 13}$, an enhancer for transcription. Binding of atRA to the RAR partner of the heterodimers activates the RAR/RXR nuclear receptor to initiate transcription of the RARE-regulated genes ${ }^{9 ; 14}$. Through activating the RAR/RXR receptors, atRA modulates the expression of over 500 protein-coding genes ${ }^{15}$ and possibly a large number of regulatory RNAs ${ }^{16}$ that are necessary for embryonic development and cellular functions in adults. RAR ligands have been found to be potent teratogens, whereas RXR ligands have not ${ }^{3}$, suggesting that retinol signaling for the regulation of embryonic development depends on atRA and the RAR receptors ${ }^{3 ;}$ 10.

The intracellular levels of $a t \mathrm{RA}$ are regulated by the retinol signaling pathway (RSP) that controls the biosynthesis and catabolism of atRA. In the RSP, retinol is oxidized to retinaldehyde (retinal) by alcohol dehydrogenases, which is subsequently oxidized to atRA by retinaldehyde dehydrogenases (Fig.1). atRA is further oxidized to polar metabolites by the Cyp26 cytochrome p450 enzymes for removal ${ }^{17}$. The RSP maintains the physiological homeostasis of atRA that is required for normal cellular functions. 
Deviation of atRA levels from cell-defined limits, which can be a result of improper administration of retinoids or dysregulation of the RSP, may be teratogenic. For example, the offspring of pregnant animals fed on vitamin A-deficient diets or diets containing excess vitamin A (presumably retinyl esters) were shown to have congenital malformations in different organs ${ }^{3 ;}$ ${ }^{10}$; the use of isotretinoin (13-cis retinoic acid) for the treatment of severe acne and skin cancers may also lead to teratogenic outcomes ${ }^{18}$. In addition, disruption of the regulatory function of the RSP can also result in abnormal levels of atRA and consequently aberrant expression of developmental genes. Therefore, chemicals that interfere with the RSP have the potential to be developmental toxicants.

A large number of chemicals found in commercial products lack toxicity data ${ }^{19}$ and to what extent these chemicals could adversely affect retinol signaling to influence embryonic development remains largely unknown. The use of animal bioassays for large-scale chemical assessment is limited due to factors such as high costs, long study periods, low-throughput, and ethical concerns over animal use. To overcome these limitations, we have developed a reporter gene cell line, designated C3RL4, to identify chemicals that disrupt the RSP using highthroughput screening. The C3RL4 clone contains a functional RSP and the firefly luciferase gene $(L u c)$ under the control of the RARE. The expression of the RARE-Luc reporter construct is determined by the intracellular concentrations of atRA, which in turn is determined by the RSP-mediated biosynthesis/degradation of atRA (Fig.1). A RARE reporter gene assay based on this clone has been developed and validated for use in a qHTS format by screening the 1,280 compound LOPAC plus a set of control chemicals in the Tox 21 robotic system $^{20 ; 21}$. A group of compounds that have not been shown previously to affect the RSP were identified and these compound activities were subsequently confirmed in a series of follow-up tests. The results 
suggest that the RARE assay is a reliable and effective approach for screening large chemical libraries to identify and prioritize potential developmental toxicants that act by interfering with retinol signaling. 


\section{Materials and Methods}

2.1 Reagents - Chemicals purchased from Cayman Chemical (Ann Arbor, MI) include 5azacytidine, Bay 11-7085, camptothecin, D-ribofuranosylbenzimidazole, $\mathrm{H}-8 \mathrm{HCl}$, kenpaullone, 3,4-Methylenedioxy- $\beta$-nitrostyrene (MNS), niclosamide, PD 98059, and topotecan hydrochloride. Citral, DMSO, LY-294002, retinol, and SU 4312 were purchased from Sigma-Aldrich (St. Louis, MO). CD437, ER50891, HX531, and SR11237 were purchased from Torcris (Minneapolis, MN). AM580 was purchased from Enzo Life Sciences (Farmingdale, NY). Chemicals were prepared as stock solution aliquots in DMSO and stored in the vapor phase of liquid nitrogen. Chemicals were protected from extended exposure to light when being prepared and used in assays. The LOPAC was purchased from Sigma-Aldrich and stored following the protocols at the National Center for Advancing Translational Sciences (NCATS) ${ }^{22}$. The Cignal lentiviral reagent, which had a lentivirus concentration of $1.7 \times 10^{7}$ transducing units (TU)/ml, was obtained from SABiosciences (Qiagen, Frederick, MD). The MTT cell viability assay kit was obtained from ATCC (Manassas, VA) and used following the manufacturer's instructions.

2.2 Cell culture - The C3H10T1/2 [clone8] cell line was obtained from ATCC (Catalog \#CCL226, Lot \#58613480) and cultured in Basal Medium Eagle medium (BME, Invitrogen, Carlsbad, CA) supplemented with 10\% heat-inactivated FBS (ATCC), $2 \mathrm{mM} \mathrm{L-glutamine,} 50 \mathrm{U} / \mathrm{ml}$ penicillin and $50 \mu \mathrm{g} / \mathrm{ml}$ streptomycin (Invitrogen) (referred to here as complete BME). All cell cultures were maintained at $37^{\circ} \mathrm{C}$ under a humidified atmosphere of $5 \% \mathrm{CO}_{2}$.

\subsection{Lentiviral transfection and establishment of stable reporter clones - The C3H10T1/2}

[clone8] cells to be transfected were seeded at 1,500 cells/well, in $100 \mu \mathrm{l}$ complete BME, in a 96-well cell culture plate and grown for $24 \mathrm{hr}$ at $37^{\circ} \mathrm{C}$ and $5 \% \mathrm{CO}_{2}$. To transfect the cells, the overnight medium was removed and $10 \mu \mathrm{l}$ of the Cignal lentiviral reagent (control cells received 
$10 \mu 1$ PBS) was added to each well followed by addition of $40 \mu 1$ of fresh complete BME. The final MOI (Multiplicity of Infection; the number of transducing lentiviral particles per cell) was approximately $50 \mathrm{TU} / \mathrm{cell}$. After $16 \mathrm{hr}$ of exposure to the lentiviral reagent, the cells were replenished with $100 \mu \mathrm{l}$ of complete BME and cultured for $24 \mathrm{hr}$ for recovery. The cells were then cultured for 2 days in complete BME containing $4 \mu \mathrm{g} / \mathrm{ml}$ puromycin (Tocris) to select the successfully transfected cells (all control cells died after 2 days of culture in this selection medium). The cells that survived puromycin selection were trypsinized and diluted using limiting-dilution method in 96-well cell culture plates to obtain cell clones. The wells containing one single cell were confirmed visually by microscopy and marked. The cells were carried, and subcultured as needed, in complete BME containing $2 \mu \mathrm{g} / \mathrm{ml}$ puromycin for at least 3 weeks. To test the responsiveness of the candidate clones to retinol induction, the cells were treated with 1 $\mu \mathrm{M}$ retinol for $6 \mathrm{hr}$ and luciferase activity was measured and compared with the control group treated with DMSO vehicle only. The selected C3RL4 clone was determined to be free of mycoplasmas contamination by PCR-based (Sigma-Aldrich, catalog \#MP2500), fluorescent staining (Invitrogen, catalog \#M7006) and mycoplasma-ribosomal-RNA/probe hybridization (R\&D Systems, catalog \#CUL001B) assays.

2.4 RARE assay in 96-well format - To run the RARE assay in a 96-well plate format, C3RL4 cells were seeded in complete BME in a white cell culture plate (Corning, NY) at 14,000 cells/well and grown overnight at $37^{\circ} \mathrm{C}$ and $5 \% \mathrm{CO}_{2}$. In the agonist-mode assay, compoundcontaining medium was added to each assay well to reach final compound concentrations ranging from $8 \mu \mathrm{M}$ to $0.5 \mathrm{nM}$ (1:4 series dilution, 8 concentrations). In the antagonist-mode assay, compound-containing medium was added to each assay well immediately followed by addition of retinol-containing medium to reach final compound concentrations ranging from 50 
$\mu \mathrm{M}$ to $3 \mathrm{nM}$ (1:4 series dilution, 8 concentrations) and $1 \mu \mathrm{M}$ retinol, respectively. The incubation was continued, protected from light exposure, for $6 \mathrm{hr}$ at $37^{\circ} \mathrm{C}$ and $5 \% \mathrm{CO}_{2}$. To terminate cell culture and measure luciferase activity, One-Glo reagent (Promega, Madison, WI) was added (1:1 volume) directly to each well and the plates were incubated (protected from light exposure) at room temperature for $30 \mathrm{~min}$. Luminescence readout for each well was measured on a GloMax Multi+ plate reader (Promega) and the Relative Luminescence Unit (RLU) was analyzed using the Instinct (Promega), Microsoft Excel and Prism (Graphpad, La Jolla, CA) software packages.

2.5 RARE assay in 1536-well format - The workflow of the RARE assay in a 1,536-well plate format is summarized in Supplemental Table 1. To run the RARE assay, C3RL4 cells in complete BME were seeded at 1,000 cells/well in solid white 1,536-well tissue culture plates (Greiner Bio-One North America, Monroe, NC) using an 8-tip dispenser (Multidrop/Thermo Fisher Scientific, Waltham, MA). After overnight growth at $37^{\circ} \mathrm{C}$ and $5 \% \mathrm{CO}_{2}$, the cells received $23 \mathrm{nl}$ of test compounds at final concentrations ranging from $46 \mu \mathrm{M}$ to $2.9 \mathrm{nM}$ (1:5 series dilution, 7 concentrations) dispensed using a pin-tool station (Kalypsys, San Diego, CA). In the antagonist-mode screen, retinol was added ( $1 \mu \mathrm{M}$ final concentration) immediately after compound addition. Dose-titration of retinol or ER50891 was included in each assay plate as a positive control for agonist- or antagonist-mode screen, respectively. DMSO was used as a vehicle control for compounds and retinol. After $6 \mathrm{hr}$ of compound exposure, $4 \mu \mathrm{l}$ of Amplite Luciferase reagent (AAT Bioquest, Inc., Sunnyvale, CA) was added to each well using a single tip dispenser to produce cell lysate. After additional $30 \mathrm{~min}$ of incubation at room temperature, luminescence readout was measured on a ViewLux plate reader (PerkinElmer, Waltham, MA) using an exposure time of 60 seconds. 
2.6 Cell viability assay - Cytotoxicity of test compounds was determined using the CellTiter-Glo (Promega) luminescent cell viability assay which quantitates the intracellular ATP indicative of the metabolically viable cells after compound exposure. In the 96-well format assays, CellTiterGlo reagent was added (1:1 volume) directly to each well after $6 \mathrm{hr}$ of compound exposure and incubation was continued at room temperature with shaking for $10 \mathrm{~min}$ and then luminescence was measured on the GloMax+ instrument. In the 1,536-well format assays, $5 \mu 1$ of CellTiterGlo reagent was added to each well using a single tip dispenser after the cells were exposed to compounds for $6 \mathrm{hr}$, and incubation was continued at room temperature for additional $30 \mathrm{~min}$ before luminescence was measured on the ViewLux plate reader.

2.7 Data analyses - Normalization and concentration-response curve fitting for the data from the primary screens were performed as previously described ${ }^{23 ; 24 ; 25}$. Briefly, raw plate reads for each titration point were first normalized relative to the positive control wells [agonist mode: $10 \mu \mathrm{M}$ retinol as $+100 \%$; antagonist mode: $1 \mu \mathrm{M}$ retinol and $23 \mu \mathrm{M}$ ER50891 as -100\%; both modes: assay buffer added DMSO only wells as $0 \%$ (basal)] and then corrected by applying a pattern correction algorithm using compound-free control plates (DMSO plates). Concentrationresponse titration points for each compound were fitted to the Hill equation and concentrations of half-maximal activities ( $\mathrm{EC}_{50}$ for agonists and $\mathrm{IC}_{50}$ antagonists) and maximal response values (efficacy) were calculated. Concentration-response curves were classified into four major classes based on potency, efficacy and quality of fit ${ }^{23}$. 


\section{Results}

\subsection{Establishment of the C3RL4 reporter gene cell line - The parental C3H10T1/2 [Clone8]}

cell line is an embryonic multipotent mesenchymal cell line capable of differentiating into the muscle, adipose, bone and cartilage cells ${ }^{26 ; 27}$. This cell is inducible for alkaline phosphatase enzyme expression by $a t \mathrm{RA}^{28}$ and the results from our preliminary tests show that this cell contains a functional RSP to metabolize retinol to atRA (unpublished data). To create stable clones, a reporter construct containing the $L u c$ gene under the control of the RARE was introduced into the $\mathrm{C} 3 \mathrm{H} 10 \mathrm{~T} 1 / 2$ [Clone8] cell using lentiviral particles. The clones that survived drug selection were tested for $L u c$ expression in response to retinol induction and among the candidates, clone C3RL4 (3H10T1/2, $\underline{\mathrm{R} A R E}-\underline{\mathrm{L} u c}$, clone \# $\underline{4})$ showed a relatively higher induction in $L u c$ expression than the others. This clone appeared to be morphologically identical to the parental cells and had a doubling time of approximately $19 \mathrm{hr}$, consistent with a previously reported study ${ }^{28}$. No cytotoxicity was detected in this cell when grown in the media containing up to $1 \%$ (v/v) DMSO during 6-hr or 24-hr culture periods. Based on these observations, the C3RL4 clone was selected for RARE assay optimization.

\subsection{Determination of RARE assay conditions and selection of control chemicals- The RARE} assay was first optimized in the 96-well plate format, in which several primary experimental conditions including medium, serum concentration (10\%), cell seeding density (14,000/well), chemical exposure time $(6 \mathrm{hr})^{29}$ and chemiluminescence assay conditions (described in Materials and Methods) were empirically determined. We then evaluated the performance of the RARE assay by testing a group of chemicals known to affect the RSP. Retinol rapidly (in $6 \mathrm{hr}$ ) induced a 7.8-fold increase of $L u c$ expression over the basal level; the $\mathrm{EC}_{50}$ value of retinol was $0.2 \pm$ $0.02 \mu \mathrm{M}$ (Fig. 2A). The ability of retinol to induce $L u c$ expression also indicated the presence of 
a functional RSP in the established C3RL4 clone. To determine which concentration of retinol to use as an inducer in the antagonist-mode assay, we conducted a dose-titration for citral, a known inhibitor of the retinal dehydrogenase RALDH2/ALDH1A2 enzyme that converts retinal to $a t \mathrm{RA}^{30}$ in the presence of various concentrations of retinol (Fig. 2B). At $1 \mu \mathrm{M}$ of retinol, where $~ 90 \%$ maximum induction was achieved (Fig. 2A), citral significantly suppressed retinolinduced $L u c$ expression with an $\mathrm{IC}_{50}$ value of $24.6 \pm 3.1 \mu \mathrm{M}$ (Fig. 2B). Based on the titration results, $1 \mu \mathrm{M}$ of retinol was selected for the antagonist-mode RARE assay.

A set of chemicals known to act on the RAR/RXR receptors to regulate gene transcription were also tested. AM580 and CD437, the selective agonists of the RAR $\alpha$ and RAR $\gamma$ receptors, respectively, were potent inducers of $L u c$ expression with $\mathrm{EC}_{50}$ values of $10.8 \pm 3.5 \mathrm{nM}$ and 67.8 $\pm 35.8 \mathrm{nM}$ (Fig. 2C \& 2E). The pan RXR agonist SR11237, however, was inactive, demonstrating that retinol signaling in C3RL4 cells is transduced via atRA and the RAR receptors. In the antagonist-mode assay, the selective RAR $\alpha$ antagonist, ER50891, showed a potent $\mathrm{IC}_{50}$ value of $21.3 \pm 6.6 \mathrm{nM}$, whereas the $\mathrm{RXR}$ antagonist $\mathrm{HX} 531$ was less potent $\left(\mathrm{IC}_{50}=\right.$ $1.91 \pm 0.5 \mu \mathrm{M})$ (Fig. 2D \& 2E) than previously reported ${ }^{31}$. Based on these results, we concluded that the RARE assay can be used to screen and identify chemicals that disrupt retinol signaling. Retinol and ER50891 were selected as the positive controls for the agonist- and antagonist-mode RARE assays, respectively.

3.3 Validation and miniaturization of the RARE assay - To validate the RARE assay for use in a qHTS format, we screened the LOPAC (1,280 compounds) plus the Tox21 88 compounds ${ }^{20 ; 21}$ in a 1,536-well plate format in both agonist- and antagonist-modes (Supplemental Table 1). In each mode, a total of 27 assay plates ( 9 plates run in triplicates) with over 41,000 samples were screened. The retinol dose-titration for the agonist-mode screen or ER50891 for the antagonist- 
mode screen was embedded in each assay plate as a positive control. Retinol and ER50891 gave an average $\mathrm{EC}_{50}$ value of $0.91 \pm 0.27 \mu \mathrm{M}$ and $\mathrm{IC}_{50}$ value of $0.03 \pm 0.01 \mu \mathrm{M}$, respectively; these values were comparable to that obtained from the 96 -well format tests. Despite a slightly high CV value (13.6\%) for the antagonist-mode screen, the primary screens yielded good performance statistics $^{24 ; 25}$ (Table 1), suggesting the robustness of the RARE assay in qHTS. A CellTiter-Glo luminescent cell viability assay that was run in parallel with the RARE assay to monitor the cytotoxicity of the test compounds also generated excellent performance statistics (Table 1).

The performance of the RARE assay in qHTS was further evaluated in terms of data reproducibility ${ }^{24 ; 32 ; 33}$. The agonist-mode screen showed $1.92 \%$ active match and only $0.26 \%$ mismatch (Table 1). The antagonist-mode screen also had good reproducibility with the exception of one inconclusive call ${ }^{24 ; 33}(43.15 \%)$ that was relatively high. Reproducibility for the viability assay was excellent with $0 \%$ mismatch (Table 1). Taken together, these results suggest that both the RARE and the viability assays are reliable and suitable for high-throughput screening of large compound libraries such as the Tox $2110 \mathrm{~K}$ compound collection.

3.4 Identification of the RSP agonists - The primary LOPAC screen in agonist-mode identified 35 hits with $\mathrm{EC}_{50}$ values of $\leq 20 \mu \mathrm{M}$ and efficacy values of $\geq 30 \%$ from triplicate runs (Supplemental Table 2). After reviewing these 35 primary hits and considering the criteria of $\mathrm{EC}_{50} \leq 15 \mu \mathrm{M}$, efficacy $\geq 30 \%$, curve ranking ${ }^{24 ; 33}$ and available publications, we selected 25 compounds (Table 2) to re-test in the RARE assay in qHTS (referred to as cherry-pick confirmation screen ${ }^{20}$ ). Activities of all 25 compounds were confirmed, with a confirmation rate of $100 \%$ and a hit rate of $1.8 \%$ out of a total of 1,368 compounds screened (1,280 plus 88$)$. For these 25 compounds, the $\mathrm{EC}_{50}$ values from the primary and cherry-pick screens correlated well with $\mathrm{R}_{\text {agonist }}=0.92^{20 ; 33}$. For each compound, the efficacy values from the two screens were also 
comparable. Of the 25 compounds, 20 showed relatively high potency $\left(\mathrm{EC}_{50} \leq 5 \mu \mathrm{M}\right)$. No cytotoxicity was detected with 22 compounds while the remaining three had only marginal cytotoxicity. For these three compounds, the $\mathrm{EC}_{50}$ values determined in the RARE assay were more than 19-fold smaller than the $\mathrm{IC}_{50}$ values determined in the cell viability assay (Table 2), suggesting that the activating effect of these compounds on the RSP was not a consequence of cytotoxic effect.

In searching the LOPAC for chemical analogs that are structurally related to retinol, we found four compounds including atRA, 13-cis retinoic acid, retinoic acid p-hydroxyanilide and astaxanthin. In addition, AC55649 and TTNPB, two known agonists of the RAR receptors, also were included in the LOPAC. Except for astaxanthin, a carotenoid without retinol activity ${ }^{34}$, the other five compounds were successfully identified in the primary screen and then confirmed in the cherry-pick screen. In addition, four compounds (Table 2) had relatively higher efficacy (> $50 \%$ ) than the rest of the identified hits. These results proved again the reliability of the RARE assay for identifying potential agonists of the RSP.

3.5 Identification of the RSP antagonists - The LOPAC screen in antagonist-mode identified 63 potential RSP antagonists which had $\mathrm{IC}_{50} \leq 16 \mu \mathrm{M}$, efficacy $\leq-50 \%$, and were at least 3-fold more potent in the RARE assay than in the cell viability counter screen (Supplemental Table 2). Twenty-eight of these compounds with $\mathrm{IC}_{50} \leq 15 \mu \mathrm{M}$ and efficacy $\leq-60 \%$ were cherry-picked and re-tested in the RARE assay (Table 3 ). For the 28 compounds, the $\mathrm{IC}_{50}$ values from the primary and cherry-pick screens correlated well with $\mathrm{R}_{\text {antagonist }}=0.79$. For each compound, the efficacy values from the two screens were also comparable (Table 3). Two compounds (emetine dihydrochloride hydrate and parthenolide) had similar $\mathrm{IC}_{50}$ values from the RARE and cell viability assays, indicating that cytotoxicity may have contributed to the inhibitory effect on 
retinol-induced $L u c$ expression. Therefore, the cherry-pick tests for the antagonists had a confirmation rate of $92.9 \%$ (26/28) and a hit rate of $1.9 \%$ out of the 1,368 compounds screened.

3.6 Powder compound confirmation - To further confirm the active compounds identified from the primary screens and confirmed in the cherry-pick screens, 12 compounds including four agonists and eight antagonists were selected based on the potency, efficacy, low cytotoxicity, and novelty for powder confirmation tests ${ }^{20}$, in which compounds were purchased and new stock solutions were prepared and re-tested in 96-well format RARE assay. A dose-response curve was generated for each compound (data not shown). At non-cytotoxic doses, the $\mathrm{EC}_{50}$ or $\mathrm{IC}_{50}$ values derived from these curves were close to those from the primary and/or the cherry-pick screens (Table $2 \& 3$ ). Therefore, the activities of all 12 compounds on the RSP were confirmed in the powder confirmation tests.

3.7 Confirmation in the P19 cell - Although it was not feasible to carry out confirmation tests for all identified compounds, we examined a few in a different cell line to determine if the activities were cell-type specific. The mouse P19 pluripotent embryonal carcinoma cell ${ }^{35}$, which contains a RSP and metabolizes retinol to $a t \mathrm{RA}^{36}$, has previously been used in a mode-of-action screen for identifying disruptors of the $\mathrm{RSP}^{29}$. Exposure of this cell to retinol rapidly induces the expression of the Hoxalgene ${ }^{36}$, a transcription factor essential for patterning in the early embryo $^{37}$. Eight compounds including four agonists and four antagonists that showed relatively high potencies were tested at non-cytotoxic doses that were chosen after reviewing the data from the primary, cherry-pick, and powder confirmation screens (Table $2 \& 3$ ) and preliminary tests (data not shown). All four agonists induced $>2$ fold increase in Hoxal expression within $6 \mathrm{hr}$ (Fig. 3). The four antagonists significantly inhibited the retinol-induced Hoxal expression (Fig.3) by at least $65 \%$ (Table $2 \& 3$ ). Therefore, these compound activities were not specific to the 
C3RL4 cell and likely, they may act through a common mechanism that also exists in other cell types such as the P19 cell to influence retinol signaling. Although it was not the primary goal of this study to define the exact mechanism of compound action on the RSP, the screens provided a set of candidates/leads for further detailed structure-activity relationship (SAR) and mechanistic studies. 


\section{Discussion}

Birth defects, which occur to approximately 120,000 ( $3 \%)$ newborns in the U.S. every year (U.S. $\mathrm{CDC}^{38}$ ), are thought to be caused by a mix of both genetic inheritance and environmental factors, which include exposure to chemicals during pregnancy. Studies have shown that maternal exposure to chemicals via certain behaviors (e.g., smoking ${ }^{39}$ ), medications ${ }^{18}$, and contaminated consumer products (e.g., heavy metal ${ }^{40}$ ) can significantly increase the risk of birth defects. Given that a large number of chemicals lack developmental toxicity data and the RSP is an important developmental signaling pathway, there is a need for qHTS methods that are capable of identifying potential disruptors of the RSP. We show that the RARE assay developed in this study is able to detect chemical interference with retinol signaling and this mode-of-action screen can be used to identify and prioritize chemicals for more detailed mechanistic studies.

Agonists - Some of the agonists identified in this study have been implicated as regulators of stem cell survival, pluripotency and differentiation, although the mechanisms remain unclear. For example, kenpaullone, an anticancer drug that inhibits CDK1/cyclin B-dependent cell proliferation ${ }^{41}$, supports the survival of motor neurons derived from pluripotent cells by inhibiting GSK-3, a key kinase in the canonical Wnt pathway ${ }^{42}$. In addition, this compound also increases differentiation of ventral midbrain precursors into dopamine neurons, an effect similar to that of the Wnts ${ }^{43}$. Moreover, kenpaullone can replace the transcription factor $\mathrm{Klf}_{4}{ }^{44}$ in the reprogramming of somatic cells to induced pluripotent stem cells ${ }^{45}$. Whether kenpaullone acts through similar mechanism as retinol/atRA, which also can induce neuron differentiation ${ }^{46}$ and maintains stem cell pluripotency ${ }^{47 ; 48}$, remain to be investigated. 
Another identified compound that has previously been shown to regulate development is the anthelmintic drug niclosamide ${ }^{49}$, which inhibits the mTOR $1^{50}, \mathrm{NF}-\mathrm{kB}^{51}, \mathrm{STAT}^{52}$ pathways as well as the key developmental signaling pathways of $\operatorname{Notch}^{53}$ and Wnt $/ \beta$-catenin ${ }^{54}$. The finding in this study that niclosamide is a potent RSP activator broadens its spectrum of targets, and indicates that niclosamide may act on multiple sites and possibly through pathway crosstalk to influence the overall developmental outcome.

PD98059, a selective inhibitor of the mitogen-activated protein kinase kinase (MAPKK/MEK) in the MAPK pathway ${ }^{55}$, inhibits atRA-induced MAPK activation ${ }^{56}$ and cell differentiation ${ }^{57}$. In addition, MAPK activation increases the expression of the $R a l d h 2^{58}$ gene that encodes the enzyme responsible for the conversion of RAL to atRA and therefore, PD98059 can inhibit MAPK-induced $a t$ RA biosynthesis ${ }^{59}$. Contrary to these previous findings, PD98059 alone was found in the present study to activate the RSP, although a relatively high dose $(\sim 10 \mu \mathrm{M})$ was required to induce the Hoxal expression in P19 cells. One possibility is that PD98059 acts directly on the RSP to enhance atRA biosynthesis. In fact, PD98059 has been found to antagonize CYP26A1 ${ }^{60}$, suggesting that PD98059 elevates atRA levels by reducing the catabolism of atRA. Furthermore, it is also conceivable that the two tested cells can establish a compensatory feedback mechanism when exposed to PD98059 to elevate the basal levels of atRA in order to cope with the anti-proliferation effect of this compound. The pleiotropic effect of PD98059 requires further studies.

To our knowledge no report has shown that SU4312 affects the RSP. This tyrosine kinase inhibitor is a selective inhibitor of the vascular endothelial growth factor (VEGF) receptors and has been used to treat cancers based on its anti-angiogenic properties ${ }^{61}$. It also has protective effects on neurons ${ }^{62}$. Although retinoids are also reported to have anti-angiogenic ${ }^{63}$ and 
neuroprotective ${ }^{64}$ properties, whether there is a correlation between the mechanisms of SU432 and retinoids is unknown.

Antagonists - The antagonists identified in this study have a variety of functions. LY294002 inhibits the phosphoinositide 3-kinase (PI3K)/Akt signaling pathway that regulates many cellular processes including atRA-induced cell differentiation ${ }^{65 ; 66}$. In addition, this compound completely blocks RALDH2 enzyme expression in human basophils ${ }^{67}$. Furthermore, LY294002 delays atRA-induced expression of certain Hox cluster genes in mouse F9 embryonic carcinoma cells $^{66}$, suggesting a PI3K/Akt-dependent regulation. These findings provide an explanation for the compound's inhibition on the Hoxal expression in P19 cells, in which the expression of both Raldh2 and Hoxal genes can be significantly induced by retinol ${ }^{36}$.

Bay 11-7085 blocks the phosphorylation of $\mathrm{I} \kappa \mathrm{B} \alpha$, whose non-phosphorylated form binds and suppresses the nuclear factor- $\kappa \mathrm{B}(\mathrm{NF}-\kappa \mathrm{B})$ transcription factor, which regulates the inflammatory response and the development of organs by signaling cell proliferation, differentiation, and apoptosis $^{68}$. Inhibition of the NF- $\mathrm{B}$ by Bay 11-7085 can cause congenital heart defects in chickens $^{69}$. Although how Bay 11-7085 affects retinol signaling is unknown, results from previous studies show that some of the retinoid-regulated processes such as apoptosis ${ }^{70}$ and gene $\operatorname{expression}^{71 ; 72}$ are NF- $\kappa \mathrm{B}$-dependent. For example, the expression of the homeobox gene $M S X$ $1 / \mathrm{HOX}-7$, which regulates craniofacial, limb and ectodermal organ morphogenesis ${ }^{73}$, is activated by atRA in human NT2/D1 cells ${ }^{72}$, and inhibition of NF- $\kappa \mathrm{B}$ decreases $m s x-1$ mRNA expression in chick embryos ${ }^{71}$. The NF-кB binding sites are present in the promoter region of this gene ${ }^{71 ; 72}$, indicating that the RSP and NF- $\mathrm{KB}$ pathway may coordinate to regulate the expression of homeobox genes, such as the Hoxal gene. 
MNS (3,4-Methylenedioxy- $\beta$-nitrostyrene) antagonizes the Src and Syk tyrosine kinases ${ }^{74}$ to inhibit platelet aggregation ${ }^{75}$, inflammatory activities ${ }^{76}$, and cancer cell phenotype ${ }^{77}$. Although the mechanism by which it influences retinol signaling is unknown, the involvement of Syk kinases in the regulation of retinoid-induced effects has been reported. For example, atRAinduced HL-60 cell differentiation requires Syk-mediated Vav tyrosine phosphorylation ${ }^{78}$, and Raldh2 expression induced by immune response in mouse splenic dendritic cells also requires Syk-dependent signaling ${ }^{58}$. The finding that MNS inhibits the RSP, possibly via the Src/Syk pathway, is consistent with the notion that retinol signaling is essential for cellular differentiation and the immune response $e^{5}$.

Finally, a few inhibitors of the topoisomerases I (camptothecin ${ }^{79}$ and topotecan ${ }^{80}$ ) and topoisomerases II (amsacrine ${ }^{81}$ and idarubicin ${ }^{82}$ ) were found to suppress retinol-induced $L u c$ expression. All of these compounds have been used as chemotherapeutic agents to attenuate cell proliferation and induce apoptosis by antagonizing the topoisomerases which otherwise relax chromosome tangles and supercoils to allow DNA replication and transcription for growth. A possible explanation is that these compounds generally inhibit transcription of genes including the $L u c$. However, certain topoisomerases may have specific effects on retinol signaling, which were described in some previous studies, albeit inconsistent conclusions can be drawn. For example, camptothecin was found to potentiate the effect of atRA on growth arrest and differentiation in the HL-60 cells ${ }^{79}$, and likewise, retinol enhanced the pro-apoptotic effect of a camptothecin analog, irinotecan ${ }^{83}$. Contrary to these findings, however, retinoids were found to suppress apoptosis in T47D breast cancer cells triggered by camptothecin and etoposide ${ }^{70}$ (a topoisomerase II inhibitor). Further studies are needed to reveal the targets and mechanisms of these compounds. 
The compounds identified in this study, some of which are approved drugs, are known to have a relatively potent effect on distinct targets, suggesting that diverse cellular sensing mechanisms and signaling pathways converge to contribute to the regulation of retinol signaling. These compounds may act directly on the RSP components to regulate gene expression or influence retinol signaling through crosstalk between the RSP and other signaling pathways, suggesting a complex and possibly redundant regulatory network (Fig. 4). Such a network can integrate a wide range of extracellular and intracellular information to regulate embryonic development, which must follow specific cascades of programmed molecular events in certain spatial and temporal orders; even a brief disruption of these precisely-orchestrated event threads has the potential to generate significant teratogenic outcomes.

In summary, we developed and validated the RARE assay for use in a qHTS format and identified a group of compounds from the LOPAC that modulate the RSP. The results suggest that the RSP is a target of regulation by many other signaling pathways, indicating a coordinated regulation by pathway crosstalk for embryonic development. These compounds therefore have the potential to be developmental toxicants. This study provides candidate chemicals for a more focused evaluation of developmental toxicity, which is expected to improve the understanding of the mechanism of compound action in the regulation of embryonic development. 


\section{Acknowledgement}

This work was supported in part through the interagency agreement IAG \#NTR 12003 from the National Institute of Environmental Health Sciences/Division of the National Toxicology Program to the National Center for Advancing Translational Sciences (NCATS), National Institutes of Health (NIH). This project was also supported in part by the appointment of Dr. Yanling Chen to the Research Participation Program at the Center for Food Safety and Applied Nutrition administrated by the Oak Ridge Institute for Science and Education through an interagency agreement between the U.S. Department of Energy and the U.S. Food and Drug Administration (U.S. FDA). This research does not necessarily reflect the statements, opinions, views, conclusions, or policies of the NCATS, the NIH, U.S. FDA, or the United States government. Mention of trade names or commercial products does not constitute endorsement or recommendation for use. 


\section{References}

1. Sporn, M. B., Dunlop, N. M., Newton, D. L. \& Smith, J. M. (1976). Prevention of chemical carcinogenesis by vitamin $A$ and its synthetic analogs (retinoids). Fed Proc 35, 1332-8.

2. Ross, S. A., McCaffery, P. J., Drager, U. C. \& De Luca, L. M. (2000). Retinoids in embryonal development. Physiol Rev 80, 1021-54.

3. Collins, M. D. \& Mao, G. E. (1999). Teratology of retinoids. Annu Rev Pharmacol Toxicol 39, 399430.

4. Duester, G. (2008). Retinoic acid synthesis and signaling during early organogenesis. Cell 134, 921-31.

5. Stephensen, C. B. (2001). Vitamin A, infection, and immune function. Annu Rev Nutr 21, 167-92.

6. Cunningham, T. J. \& Duester, G. (2015). Mechanisms of retinoic acid signalling and its roles in organ and limb development. Nat Rev Mol Cell Biol 16, 110-23.

7. Janesick, A., Wu, S. C. \& Blumberg, B. (2015). Retinoic acid signaling and neuronal differentiation. Cell Mol Life Sci 72, 1559-76.

8. Napoli, J. L. (2012). Physiological insights into all-trans-retinoic acid biosynthesis. Biochim Biophys Acta 1821, 152-67.

9. Chambon, P. (1996). A decade of molecular biology of retinoic acid receptors. FASEB J 10, 94054.

10. Mark, M., Ghyselinck, N. B. \& Chambon, P. (2009). Function of retinoic acid receptors during embryonic development. Nucl Recept Signal 7, e002.

11. Evans, R. M. \& Mangelsdorf, D. J. (2014). Nuclear Receptors, RXR, and the Big Bang. Cell 157, 255-66.

12. Mader, S., Leroy, P., Chen, J. Y. \& Chambon, P. (1993). Multiple parameters control the selectivity of nuclear receptors for their response elements. Selectivity and promiscuity in response element recognition by retinoic acid receptors and retinoid $\mathrm{X}$ receptors. $J$ Biol Chem 268, 591-600.

13. Kurokawa, R., DiRenzo, J., Boehm, M., Sugarman, J., Gloss, B., Rosenfeld, M. G., Heyman, R. A. \& Glass, C. K. (1994). Regulation of retinoid signalling by receptor polarity and allosteric control of ligand binding. Nature 371, 528-31.

14. Rochette-Egly, C. (2015). Retinoic acid signaling and mouse embryonic stem cell differentiation: Cross talk between genomic and non-genomic effects of RA. Biochim Biophys Acta 1851, 66-75.

15. Balmer, J. E. \& Blomhoff, R. (2002). Gene expression regulation by retinoic acid. J Lipid Res 43, 1773-808.

16. Cawley, S., Bekiranov, S., Ng, H. H., Kapranov, P., Sekinger, E. A., Kampa, D., Piccolboni, A., Sementchenko, V., Cheng, J., Williams, A. J., Wheeler, R., Wong, B., Drenkow, J., Yamanaka, M., Patel, S., Brubaker, S., Tammana, H., Helt, G., Struhl, K. \& Gingeras, T. R. (2004). Unbiased mapping of transcription factor binding sites along human chromosomes 21 and 22 points to widespread regulation of noncoding RNAs. Cell 116, 499-509.

17. Sonneveld, E., van den Brink, C. E., Tertoolen, L. G., van der Burg, B. \& van der Saag, P. T. (1999). Retinoic acid hydroxylase (CYP26) is a key enzyme in neuronal differentiation of embryonal carcinoma cells. Dev Biol 213, 390-404.

18. Goldsmith, L. A., Bolognia, J. L., Callen, J. P., Chen, S. C., Feldman, S. R., Lim, H. W., Lucky, A. W., Reed, B. R., Siegfried, E. C., Thiboutot, D. M., Wheeland, R. G. \& American Academy of, D. (2004). American Academy of Dermatology Consensus Conference on the safe and optimal use of isotretinoin: summary and recommendations. J Am Acad Dermatol 50, 900-6. 
19. Judson, R., Richard, A., Dix, D. J., Houck, K., Martin, M., Kavlock, R., Dellarco, V., Henry, T., Holderman, T., Sayre, P., Tan, S., Carpenter, T. \& Smith, E. (2009). The toxicity data landscape for environmental chemicals. Environ Health Perspect 117, 685-95.

20. Sakamuru, S., Li, X., Attene-Ramos, M. S., Huang, R., Lu, J., Shou, L., Shen, M., Tice, R. R., Austin, C. P. \& Xia, M. (2012). Application of a homogenous membrane potential assay to assess mitochondrial function. Physiol Genomics 44, 495-503.

21. Attene-Ramos, M. S., Miller, N., Huang, R., Michael, S., Itkin, M., Kavlock, R. J., Austin, C. P., Shinn, P., Simeonov, A., Tice, R. R. \& Xia, M. (2013). The Tox21 robotic platform for the assessment of environmental chemicals - from vision to reality. Drug Discov Today 18, 716-23.

22. Xia, M., Guo, V., Huang, R., Inglese, J., Nirenberg, M. \& Austin, C. P. (2009). A Cell-based betaLactamase Reporter Gene Assay for the CREB Signaling Pathway. Curr Chem Genomics 3, 7-12.

23. Inglese, J., Auld, D. S., Jadhav, A., Johnson, R. L., Simeonov, A., Yasgar, A., Zheng, W. \& Austin, C. P. (2006). Quantitative high-throughput screening: a titration-based approach that efficiently identifies biological activities in large chemical libraries. Proc Natl Acad Sci U S A 103, 11473-8.

24. Huang, R., Xia, M., Cho, M. H., Sakamuru, S., Shinn, P., Houck, K. A., Dix, D. J., Judson, R. S., Witt, K. L., Kavlock, R. J., Tice, R. R. \& Austin, C. P. (2011). Chemical genomics profiling of environmental chemical modulation of human nuclear receptors. Environ Health Perspect 119, 1142-8.

25. Zhang, J. H., Chung, T. D. \& Oldenburg, K. R. (1999). A Simple Statistical Parameter for Use in Evaluation and Validation of High Throughput Screening Assays. J Biomol Screen 4, 67-73.

26. Reznikoff, C. A., Brankow, D. W. \& Heidelberger, C. (1973). Establishment and characterization of a cloned line of $\mathrm{C} 3 \mathrm{H}$ mouse embryo cells sensitive to postconfluence inhibition of division. Cancer Res 33, 3231-8.

27. Hisada, K., Hata, K., Ichida, F., Matsubara, T., Orimo, H., Nakano, T., Yatani, H., Nishimura, R. \& Yoneda, T. (2013). Retinoic acid regulates commitment of undifferentiated mesenchymal stem cells into osteoblasts and adipocytes. J Bone Miner Metab 31, 53-63.

28. Reese, D. H., Larsen, R. A. \& Hornicek, F. J. (1992). Control of alkaline phosphatase activity in C3H10T1/2 cells: role of retinoic acid and cell density. J Cell Physiol 151, 239-48.

29. Chen, Y. \& Reese, D. H. (2013). A Screen for Disruptors of the Retinol (Vitamin A) Signaling Pathway. Birth Defects Res B Dev Reprod Toxicol.

30. Gagnon, I., Duester, G. \& Bhat, P. V. (2002). Kinetic analysis of mouse retinal dehydrogenase type-2 (RALDH2) for retinal substrates. Biochim Biophys Acta 1596, 156-62.

31. Ebisawa, M., Umemiya, H., Ohta, K., Fukasawa, H., Kawachi, E., Christoffel, G., Gronemeyer, H., Tsuji, M., Hashimoto, Y., Shudo, K. \& Kagechika, H. (1999). Retinoid X receptor-antagonistic diazepinylbenzoic acids. Chem Pharm Bull (Tokyo) 47, 1778-86.

32. Attene-Ramos, M. S., Huang, R., Michael, S., Witt, K. L., Richard, A., Tice, R. R., Simeonov, A., Austin, C. P. \& Xia, M. (2015). Profiling of the Tox21 chemical collection for mitochondrial function to identify compounds that acutely decrease mitochondrial membrane potential. Environ Health Perspect 123, 49-56.

33. Huang, R., Sakamuru, S., Martin, M. T., Reif, D. M., Judson, R. S., Houck, K. A., Casey, W., Hsieh, J. H., Shockley, K. R., Ceger, P., Fostel, J., Witt, K. L., Tong, W., Rotroff, D. M., Zhao, T., Shinn, P., Simeonov, A., Dix, D. J., Austin, C. P., Kavlock, R. J., Tice, R. R. \& Xia, M. (2014). Profiling of the Tox21 10K compound library for agonists and antagonists of the estrogen receptor alpha signaling pathway. Sci Rep 4, 5664.

34. Jyonouchi, H., Sun, S., Tomita, Y. \& Gross, M. D. (1995). Astaxanthin, a carotenoid without vitamin A activity, augments antibody responses in cultures including T-helper cell clones and suboptimal doses of antigen. J Nutr 125, 2483-92. 
35. van der Heyden, M. A. \& Defize, L. H. (2003). Twenty one years of P19 cells: what an embryonal carcinoma cell line taught us about cardiomyocyte differentiation. Cardiovasc Res 58, 292-302.

36. Chen, Y. \& Reese, D. H. (2011). The retinol signaling pathway in mouse pluripotent P19 cells. J Cell Biochem 112, 2865-72.

37. Tischfield, M. A., Bosley, T. M., Salih, M. A., Alorainy, I. A., Sener, E. C., Nester, M. J., Oystreck, D. T., Chan, W. M., Andrews, C., Erickson, R. P. \& Engle, E. C. (2005). Homozygous HOXA1 mutations disrupt human brainstem, inner ear, cardiovascular and cognitive development. Nat Genet 37, 1035-7.

38. Rynn, L., Cragan, J. \& Correa, A. (2008). Update on Overall Prevalence of Major Birth Defects. JAMA 299, 756-758.

39. Hackshaw, A., Rodeck, C. \& Boniface, S. (2011). Maternal smoking in pregnancy and birth defects: a systematic review based on 173687 malformed cases and 11.7 million controls. Hum Reprod Update 17, 589-604.

40. Needham, L. L., Barr, D. B., Caudill, S. P., Pirkle, J. L., Turner, W. E., Osterloh, J., Jones, R. L. \& Sampson, E. J. (2005). Concentrations of environmental chemicals associated with neurodevelopmental effects in U.S. population. Neurotoxicology 26, 531-45.

41. Zaharevitz, D. W., Gussio, R., Leost, M., Senderowicz, A. M., Lahusen, T., Kunick, C., Meijer, L. \& Sausville, E. A. (1999). Discovery and initial characterization of the paullones, a novel class of small-molecule inhibitors of cyclin-dependent kinases. Cancer Res 59, 2566-9.

42. Yang, Y. M., Gupta, S. K., Kim, K. J., Powers, B. E., Cerqueira, A., Wainger, B. J., Ngo, H. D., Rosowski, K. A., Schein, P. A., Ackeifi, C. A., Arvanites, A. C., Davidow, L. S., Woolf, C. J. \& Rubin, L. L. (2013). A small molecule screen in stem-cell-derived motor neurons identifies a kinase inhibitor as a candidate therapeutic for ALS. Cell Stem Cell 12, 713-26.

43. Castelo-Branco, G., Rawal, N. \& Arenas, E. (2004). GSK-3beta inhibition/beta-catenin stabilization in ventral midbrain precursors increases differentiation into dopamine neurons. $J$ Cell Sci 117, 5731-7.

44. Takahashi, K. \& Yamanaka, S. (2006). Induction of pluripotent stem cells from mouse embryonic and adult fibroblast cultures by defined factors. Cell 126, 663-76.

45. Lyssiotis, C. A., Foreman, R. K., Staerk, J., Garcia, M., Mathur, D., Markoulaki, S., Hanna, J., Lairson, L. L., Charette, B. D., Bouchez, L. C., Bollong, M., Kunick, C., Brinker, A., Cho, C. Y., Schultz, P. G. \& Jaenisch, R. (2009). Reprogramming of murine fibroblasts to induced pluripotent stem cells with chemical complementation of Klf4. Proc Natl Acad Sci U S A 106, 8912-7.

46. Jones-Villeneuve, E. M., McBurney, M. W., Rogers, K. A. \& Kalnins, V. I. (1982). Retinoic acid induces embryonal carcinoma cells to differentiate into neurons and glial cells. J Cell Biol 94, 253-62.

47. Li, W. \& Ding, S. (2010). Small molecules that modulate embryonic stem cell fate and somatic cell reprogramming. Trends Pharmacol Sci 31, 36-45.

48. Chen, L. \& Khillan, J. S. (2008). Promotion of feeder-independent self-renewal of embryonic stem cells by retinol (vitamin A). Stem Cells 26, 1858-64.

49. Li, Y., Li, P. K., Roberts, M. J., Arend, R. C., Samant, R. S. \& Buchsbaum, D. J. (2014). Multitargeted therapy of cancer by niclosamide: A new application for an old drug. Cancer Lett 349, 814.

50. Fonseca, B. D., Diering, G. H., Bidinosti, M. A., Dalal, K., Alain, T., Balgi, A. D., Forestieri, R., Nodwell, M., Rajadurai, C. V., Gunaratnam, C., Tee, A. R., Duong, F., Andersen, R. J., Orlowski, J., Numata, M., Sonenberg, N. \& Roberge, M. (2012). Structure-activity analysis of niclosamide reveals potential role for cytoplasmic $\mathrm{pH}$ in control of mammalian target of rapamycin complex 1 (mTORC1) signaling. J Biol Chem 287, 17530-45. 
51. Jin, Y., Lu, Z., Ding, K., Li, J., Du, X., Chen, C., Sun, X., Wu, Y., Zhou, J. \& Pan, J. (2010). Antineoplastic mechanisms of niclosamide in acute myelogenous leukemia stem cells: inactivation of the NF-kappaB pathway and generation of reactive oxygen species. Cancer Res 70, 2516-27.

52. Ren, X., Duan, L., He, Q., Zhang, Z., Zhou, Y., Wu, D., Pan, J., Pei, D. \& Ding, K. (2010). Identification of Niclosamide as a New Small-Molecule Inhibitor of the STAT3 Signaling Pathway. ACS Med Chem Lett 1, 454-9.

53. Wang, A. M., Ku, H. H., Liang, Y. C., Chen, Y. C., Hwu, Y. M. \& Yeh, T. S. (2009). The autonomous notch signal pathway is activated by baicalin and baicalein but is suppressed by niclosamide in K562 cells. J Cell Biochem 106, 682-92.

54. Chen, M., Wang, J., Lu, J., Bond, M. C., Ren, X. R., Lyerly, H. K., Barak, L. S. \& Chen, W. (2009). The anti-helminthic niclosamide inhibits Wnt/Frizzled1 signaling. Biochemistry 48, 10267-74.

55. Murphy, L. O. \& Blenis, J. (2006). MAPK signal specificity: the right place at the right time. Trends Biochem Sci 31, 268-75.

56. Yen, A., Roberson, M. S., Varvayanis, S. \& Lee, A. T. (1998). Retinoic acid induced mitogenactivated protein (MAP)/extracellular signal-regulated kinase (ERK) kinase-dependent MAP kinase activation needed to elicit HL-60 cell differentiation and growth arrest. Cancer Res 58, 3163-72.

57. Bost, F., Caron, L., Marchetti, I., Dani, C., Le Marchand-Brustel, Y. \& Binetruy, B. (2002). Retinoic acid activation of the ERK pathway is required for embryonic stem cell commitment into the adipocyte lineage. Biochem $J$ 361, 621-7.

58. Manicassamy, S., Ravindran, R., Deng, J., Oluoch, H., Denning, T. L., Kasturi, S. P., Rosenthal, K. M., Evavold, B. D. \& Pulendran, B. (2009). Toll-like receptor 2-dependent induction of vitamin Ametabolizing enzymes in dendritic cells promotes $T$ regulatory responses and inhibits autoimmunity. Nat Med 15, 401-9.

59. Ohoka, Y., Yokota-Nakatsuma, A., Maeda, N., Takeuchi, H. \& Iwata, M. (2014). Retinoic acid and GM-CSF coordinately induce retinal dehydrogenase 2 (RALDH2) expression through cooperation between the RAR/RXR complex and Sp1 in dendritic cells. PLoS One 9, e96512.

60. Osanai, M., Sawada, N. \& Lee, G. H. (2010). Oncogenic and cell survival properties of the retinoic acid metabolizing enzyme, CYP26A1. Oncogene 29, 1135-44.

61. Tran, T. C., Sneed, B., Haider, J., Blavo, D., White, A., Aiyejorun, T., Baranowski, T. C., Rubinstein, A. L., Doan, T. N., Dingledine, R. \& Sandberg, E. M. (2007). Automated, quantitative screening assay for antiangiogenic compounds using transgenic zebrafish. Cancer Res 67, 11386-92.

62. Cui, W., Zhang, Z., Li, W., Hu, S., Mak, S., Zhang, H., Han, R., Yuan, S., Li, S., Sa, F., Xu, D., Lin, Z., Zuo, Z., Rong, J., Ma, E. D., Choi, T. C., Lee, S. M. \& Han, Y. (2013). The anti-cancer agent SU4312 unexpectedly protects against MPP(+) -induced neurotoxicity via selective and direct inhibition of neuronal NOS. Br J Pharmacol 168, 1201-14.

63. Hoffmann, S., Rockenstein, A., Ramaswamy, A., Celik, I., Wunderlich, A., Lingelbach, S., Hofbauer, L. C. \& Zielke, A. (2007). Retinoic acid inhibits angiogenesis and tumor growth of thyroid cancer cells. Mol Cell Endocrinol 264, 74-81.

64. Sodhi, R. K. \& Singh, N. (2014). Retinoids as potential targets for Alzheimer's disease. Pharmacol Biochem Behav 120, 117-23.

65. Matkovic, K., Brugnoli, F., Bertagnolo, V., Banfic, H. \& Visnjic, D. (2006). The role of the nuclear Akt activation and Akt inhibitors in all-trans-retinoic acid-differentiated HL-60 cells. Leukemia 20, 941-51.

66. Lee, Y., Lee, J. Y. \& Kim, M. H. (2014). PI3K/Akt pathway regulates retinoic acid-induced Hox gene expression in F9 cells. Dev Growth Differ 56, 518-25. 
67. Spiegl, N., Didichenko, S., McCaffery, P., Langen, H. \& Dahinden, C. A. (2008). Human basophils activated by mast cell-derived IL-3 express retinaldehyde dehydrogenase-II and produce the immunoregulatory mediator retinoic acid. Blood 112, 3762-71.

68. Hayden, M. S. \& Ghosh, S. (2008). Shared principles in NF-kappaB signaling. Cell 132, 344-62.

69. Hernandez-Gutierrez, S., Garcia-Pelaez, I., Zentella-Dehesa, A., Ramos-Kuri, M., HernandezFranco, P., Hernandez-Sanchez, F. \& Rojas, E. (2006). NF-kappaB signaling blockade by Bay 117085 during early cardiac morphogenesis induces alterations of the outflow tract in chicken heart. Apoptosis 11, 1101-9.

70. Jimenez-Lara, A. M., Aranda, A. \& Gronemeyer, H. (2010). Retinoic acid protects human breast cancer cells against etoposide-induced apoptosis by NF-kappaB-dependent but cIAP2independent mechanisms. Mol Cancer 9, 15.

71. Bushdid, P. B., Chen, C. L., Brantley, D. M., Yull, F., Raghow, R., Kerr, L. D. \& Barnett, J. V. (2001). NF-kappaB mediates FGF signal regulation of msx-1 expression. Dev Biol 237, 107-15.

72. Shen, R., Chen, Y., Huang, L., Vitale, E. \& Solursh, M. (1994). Characterization of the human MSX1 promoter and an enhancer responsible for retinoic acid induction. Cell Mol Biol Res 40, 297312.

73. Alappat, S., Zhang, Z. Y. \& Chen, Y. P. (2003). Msx homeobox gene family and craniofacial development. Cell Res 13, 429-42.

74. Bradshaw, J. M. (2010). The Src, Syk, and Tec family kinases: distinct types of molecular switches. Cell Signal 22, 1175-84.

75. Wang, W. Y., Hsieh, P. W., Wu, Y. C. \& Wu, C. C. (2007). Synthesis and pharmacological evaluation of novel beta-nitrostyrene derivatives as tyrosine kinase inhibitors with potent antiplatelet activity. Biochem Pharmacol 74, 601-11.

76. He, Y., Varadarajan, S., Munoz-Planillo, R., Burberry, A., Nakamura, Y. \& Nunez, G. (2014). 3,4methylenedioxy-beta-nitrostyrene inhibits NLRP3 inflammasome activation by blocking assembly of the inflammasome. J Biol Chem 289, 1142-50.

77. Messerschmitt, P. J., Rettew, A. N., Schroeder, N. O., Brookover, R. E., Jakatdar, A. P., Getty, P. J. \& Greenfield, E. M. (2012). Osteosarcoma Phenotype Is Inhibited by 3,4-Methylenedioxy-betanitrostyrene. Sarcoma 2012, 479712.

78. Bertagnolo, V., Marchisio, M., Brugnoli, F., Bavelloni, A., Boccafogli, L., Colamussi, M. L. \& Capitani, S. (2001). Requirement of tyrosine-phosphorylated Vav for morphological differentiation of all-trans-retinoic acid-treated HL-60 cells. Cell Growth Differ 12, 193-200.

79. Jing, Y., Hashimoto, S., Nakajo, S. \& Nakaya, K. (1994). Topoisomerase inhibitors potentiate the effect of retinoic acid on cell growth inhibition and induction of differentiation of leukemia HL60 cells. Leuk Res 18, 299-304.

80. Arun, B. \& Frenkel, E. P. (2001). Topoisomerase I inhibition with topotecan: pharmacologic and clinical issues. Expert Opin Pharmacother 2, 491-505.

81. Ketron, A. C., Denny, W. A., Graves, D. E. \& Osheroff, N. (2012). Amsacrine as a topoisomerase II poison: importance of drug-DNA interactions. Biochemistry 51, 1730-9.

82. Fujisawa, T., Takeda, J., Aoki, K. \& Ishikawa, T. (2014). Successful treatment of high-risk acute promyelocytic leukemia in very elderly patients using all-trans retinoic acid plus reduced-dose idarubicin. Ann Hematol 93, 1621-3.

83. Kontek, R., Jakubczak, M. \& Matlawska-Wasowska, K. (2014). The antioxidants, vitamin A and E but not vitamin $C$ and melatonin enhance the proapoptotic effects of irinotecan in cancer cells in vitro. Toxicol In Vitro 28, 282-91. 


\section{Figure captions}

Figure 1. Major steps in the RSP and the RARE-Luc reporter construct in C3RL4 cells. Retinol is converted to retinal and then to atRA via two enzymatic reactions in the RSP. atRA is an activating ligand for the RAR/RXR nuclear receptors that bind to the RARE to regulate downstream gene expression.

Figure 2. RARE assay optimization in 96-well format. (A) Retinol dose-dependent expression of $L u c$ (open diamond) in C3RL4 cells. Closed diamonds indicate relative cell viability. (B) Citral inhibits the $L u c$ expression that was induced by retinol at different concentrations. Closed diamonds indicate relative cell viability. (C) Compound dose-dependent induction of Luc expression by agonists of the RAR/RXR receptors. Open shapes indicate relative Luc expression; closed shapes indicate cell viability. (D) Inhibition of retinol-induced Luc expression by antagonists of the RAR/RXR receptors. (E) $\mathrm{EC}_{50} / \mathrm{IC}_{50}$ values of the tested compounds. RLU, Relative Luminescence Units. Values are expressed as mean \pm s.e.m.; $n=8$.

Figure 3. Compound effect on the Hoxal gene expression in P19 cells. (A) The relative Hoxal gene expression levels in cells that were treated with indicated compounds for $6 \mathrm{hr}$. ${ }^{*}, p$ $<.01$, compared to the DMSO-treated control. (B) Inhibition of retinol-induced Hoxal gene expression by the indicated compounds. *, $p<.01$, compared to the retinol-treated control. The floating bars show relative P19 cell viability determined in the MTT assays. Values are expressed as mean \pm s.e.m.; $n=4$.

Figure 4. Possible interactions between compounds and signaling pathways/biological processes. Diagram is drawn based on published literatures. Pathway crosstalk and the regulatory effects on each other are shown as arrows to indicate activation or inhibition. Dashed lines indicate that further mechanistic studies are required to prove direct compound action on the RSP. 
Table-1

\begin{tabular}{|c|c|c|c|c|c|c|c|c|}
\hline \multirow{2}{*}{ Assay Type } & \multicolumn{3}{|c|}{ General Statistics } & \multicolumn{5}{|c|}{ Reproducibility for Validation } \\
\hline & S/B (fold) & CV (\%) & $\mathbf{Z}$ & Active match & Inactive match & Mismatch & Inconclusive & $\mathrm{AC}_{50}$ fold difference ${ }^{\star \star}$ \\
\hline Agonist-mode RARE Assay & $4.12 \pm 0.45$ & $9.61 \pm 1.9^{*}$ & $0.52 \pm 0.11$ & $1.92 \%$ & $73.85 \%$ & $0.26 \%$ & $23.95 \%$ & $1.27[226]$ \\
\hline Antagonist-mode RARE Assay & $5.48 \pm 0.78$ & $13.59 \pm 1.07^{*}$ & $0.42 \pm 0.1$ & $2.55 \%$ & $51.17 \%$ & $3.11 \%$ & $43.15 \%$ & $1.60[280]$ \\
\hline CellTiter-Glo Viability Assay & $42.39 \pm 1.35$ & $4.85 \pm 0.89$ & $0.90 \pm 0.02$ & $0.97 \%$ & $91.74 \%$ & $0.00 \%$ & $7.28 \%$ & $1.19[80]$ \\
\hline
\end{tabular}

S/B, Signal-to-Background ratio; CV, Coefficent of Variation

${ }^{*} \mathrm{CV}$ values shown represent average of all plates excluding the top concentration plate

** Numbers shown are fold change and counts (in brackets); No class 4 curves. 
Table-2

\begin{tabular}{|c|c|c|c|c|c|c|c|c|c|}
\hline \multicolumn{2}{|l|}{ Compounds } & \multicolumn{2}{|c|}{ Primary Screen } & \multicolumn{3}{|c|}{ Cherry-Pick Confirmation } & \multirow{2}{*}{$\begin{array}{c}\begin{array}{c}\text { Powder } \\
\text { Confirmation }\end{array} \\
\mathrm{EC}_{50}(\mu \mathrm{M})\end{array}$} & \multicolumn{2}{|c|}{ P19 cell Confirmation } \\
\hline Name & CAS\# & $\begin{array}{l}E C_{50} \\
(\mu \mathrm{M})\end{array}$ & $\begin{array}{c}\text { Efficacy } \\
(\%)\end{array}$ & $\begin{array}{l}E^{E C_{50}} \\
(\mu \mathrm{M})\end{array}$ & $\begin{array}{c}\text { Efficacy } \\
(\%)\end{array}$ & $\begin{array}{l}\text { Cell Viability } \\
\mathrm{IC}_{50}(\mu \mathrm{M})\end{array}$ & & $\begin{array}{c}\text { Concentration } \\
(\mu \mathrm{M})\end{array}$ & $\begin{array}{l}\text { Induction } \\
\text { (fold) }\end{array}$ \\
\hline 1,10-Phenanthroline monohydrate & $5144-89-8$ & 12.83 & 245.66 & 10.49 & 47.83 & inactive & & & \\
\hline 10058-F4 & $403811-55-2$ & 11.88 & 35.70 & 16.63 & 34.98 & inactive & & & \\
\hline 4-Aminoazobenzene & $60-09-3$ & 0.69 & 36.92 & 1.21 & 40.12 & inactive & & & \\
\hline AC-55649 & $59662-49-6$ & 0.98 & 80.68 & 0.77 & 58.99 & inactive & & & \\
\hline BF-170 hydrochloride & 22191-97-5 & 0.31 & 38.22 & 0.74 & 44.25 & inactive & & & \\
\hline DFB & $15332-10-2$ & 0.91 & 36.54 & 1.94 & 46.44 & inactive & & & \\
\hline GW9662 & 22978-25-2 & 6.19 & 40.90 & 8.02 & 44.99 & inactive & & & \\
\hline K114 & $872201-12-2$ & 10.59 & 37.01 & 9.35 & 42.22 & inactive & & & \\
\hline Kenpaullone & $142273-20-9$ & 0.12 & 30.53 & 0.15 & 33.17 & 12.23 & 0.02 & 2.0 & 3.20 \\
\hline 13-cis-retinoic acid & $4759-48-2$ & 0.39 & 80.05 & 1.43 & 77.84 & inactive & & & \\
\hline Niclosamide & $50-65-7$ & 0.07 & 54.20 & 0.06 & 40.97 & 1.13 & 0.01 & 0.2 & 2.03 \\
\hline PD 98,059 & $167869-21-8$ & 1.06 & 35.56 & 1.32 & 48.92 & inactive & 0.31 & 10.0 & 2.09 \\
\hline Retinoic acid & $302-79-4$ & 0.09 & 93.20 & 0.09 & 72.60 & inactive & & & \\
\hline Retinoic acid p-hydroxyanilide & $65646-68-6$ & 2.37 & 31.31 & 5.90 & 38.22 & inactive & & & \\
\hline Rhodblock 6 & $886625-06-5$ & 8.41 & 53.17 & 3.72 & 50.38 & inactive & & & \\
\hline Rutaecarpine & $84-26-4$ & 0.47 & 40.27 & 0.34 & 39.92 & inactive & & & \\
\hline SB 204741 & $152239-46-8$ & 6.68 & 34.84 & 10.10 & 45.60 & inactive & & & \\
\hline SB 206553 hydrochloride & 1197334-04-5 & 5.31 & 32.06 & 2.35 & 24.38 & inactive & & & \\
\hline SB-366791 & 472981-92-3 & 0.69 & 35.55 & 0.87 & 39.00 & inactive & & & \\
\hline SCH 58261 & $160098-96-4$ & 2.37 & 31.24 & 2.44 & 40.53 & inactive & & & \\
\hline SIB 1757 & 1993-01-8 & 2.28 & 70.57 & 0.83 & 40.96 & 16.00 & & & \\
\hline SIB 1893 & 6266-99-5 & 2.11 & 40.15 & 1.48 & 39.27 & inactive & & & \\
\hline SU 4312 & $5812-07-7$ & 0.29 & 41.19 & 0.61 & 42.91 & inactive & 0.130 & 2.0 & 2.07 \\
\hline TTNPB & $71441-28-6$ & 3.83 & 101.76 & 0.01 & 120.56 & inactive & & & \\
\hline Tyrphostin AG 494 & $133550-35-3$ & 13.85 & 63.30 & 4.87 & 40.48 & inactive & & & \\
\hline
\end{tabular}




\section{Table-3}

\begin{tabular}{|c|c|c|c|c|c|c|c|c|c|}
\hline \multicolumn{2}{|l|}{ Compounds } & \multicolumn{2}{|c|}{$\begin{array}{l}\text { LOPAC Primary } \\
\text { Screen }\end{array}$} & \multicolumn{3}{|c|}{ Cherry-Pick Confirmation } & \multirow{2}{*}{$\begin{array}{c}\begin{array}{c}\text { Powder } \\
\text { Confirmation }\end{array} \\
\text { IC50 }(\mu \mathrm{M})\end{array}$} & \multicolumn{2}{|c|}{ P19 Cell Confirmation } \\
\hline Name & CAS\# & IC50 ( $\mu \mathrm{M})$ & $\begin{array}{c}\text { Efficacy } \\
(\%)\end{array}$ & IC50 ( $\mu \mathrm{M})$ & $\begin{array}{c}\text { Efficacy } \\
(\%)\end{array}$ & $\begin{array}{l}\text { Cell Viability } \\
\text { IC50 }(\mu \mathrm{M})\end{array}$ & & $\begin{array}{c}\text { Concentration } \\
(\mu \mathrm{M})\end{array}$ & $\begin{array}{c}\text { Inhibition } \\
(\%)\end{array}$ \\
\hline 5-azacytidine & $320-67-2$ & 8.41 & -85.14 & 18.65 & -97.77 & inactive & 7.71 & & \\
\hline Amoxapine & $14028-44-5$ & 14.96 & -64.56 & 17.61 & -59.42 & inactive & & & \\
\hline Amsacrine hydrochloride & $54301-15-4$ & 0.36 & -67.36 & 0.21 & -99.72 & 20.93 & & & \\
\hline Auranofin & $34031-32-8$ & 1.10 & -102.99 & 5.68 & -127.81 & 37.22 & & & \\
\hline Bay 11-7085 & $196309-76-9$ & 1.26 & -129.93 & 6.13 & -135.68 & 37.22 & 3.68 & 2.50 & $25.8 \%$ \\
\hline BAY 61-3606 hydrochloride hydrate & $732983-37-8$ & 1.50 & -83.19 & 2.01 & -104.73 & inactive & & & \\
\hline Brefeldin A from Penicillium brefeldianum & $20350-15-6$ & 0.72 & -63.05 & 0.83 & -67.63 & inactive & & & \\
\hline Camptothecin & 7689-03-4 & 1.96 & -75.42 & 1.87 & -133.79 & inactive & 0.27 & 0.50 & $25.9 \%$ \\
\hline CGP-74514A hydrochloride & $1173021-98-1$ & 2.98 & -110.32 & 1.80 & -112.16 & 7.72 & & & \\
\hline CGP-7930 & $57717-80-3$ & 2.28 & -63.99 & 3.07 & -83.79 & 37.22 & & & \\
\hline Desipramine hydrochloride & $58-28-6$ & 11.88 & -80.94 & 13.72 & -53.36 & inactive & & & \\
\hline Dilazep hydrochloride & 20153-98-4 & 5.96 & -76.88 & 12.23 & -83.18 & inactive & & & \\
\hline D-ribofuranosylbenzimidazole & 53-85-0 & 10.59 & -79.39 & 15.40 & -86.60 & inactive & 10.64 & & \\
\hline Emetine dihydrochloride hydrate & 7083-71-8 & 0.27 & -108.48 & 0.21 & -122.04 & 0.28 & & & \\
\hline H-8 dihydrochloride & 113276-94-1 & 11.44 & -106.84 & 20.14 & -76.51 & inactive & 16.82 & & \\
\hline \begin{tabular}{|l} 
Idarubicin hydrochloride \\
\end{tabular} & $57852-57-0$ & 4.73 & -99.51 & 0.40 & -131.34 & 37.22 & & & \\
\hline LY-294,002 hydrochloride & $934389-88-5$ & 6.68 & -62.92 & 15.40 & -91.03 & inactive & 6.09 & 5.00 & $34.0 \%$ \\
\hline Mifepristone & $84371-65-3$ & 9.44 & -88.07 & 20.93 & -86.14 & inactive & & & \\
\hline \begin{tabular}{|l|} 
Mitoxantrone \\
\end{tabular} & $70476-82-3$ & 0.84 & -98.74 & 0.83 & -154.40 & 25.36 & & & \\
\hline MNS & $1485-00-3$ & 13.33 & -128.62 & 9.72 & -127.86 & inactive & 8.43 & 2.50 & $12.1 \%$ \\
\hline \begin{tabular}{|l|} 
Parthenolide \\
\end{tabular} & 20554-84-1 & 4.06 & -96.50 & 6.13 & -136.36 & 7.87 & & & \\
\hline PD-166285 hydrate & $212391-63-4$ & 12.83 & -110.00 & 6.13 & -131.14 & 25.36 & & & \\
\hline Spironolactone & 52-01-7 & 11.88 & -62.82 & 26.35 & -67.54 & inactive & & & \\
\hline Stattic & $19983-44-9$ & 2.87 & -101.67 & 5.06 & -121.79 & 37.22 & & & \\
\hline \begin{tabular}{|l} 
Topotecan hydrochloride hydrate \\
\end{tabular} & 119413-54-6 & 8.41 & -99.60 & 2.64 & -80.02 & inactive & 11.31 & & \\
\hline UCL 2077 & 918311-87-2 & 5.52 & -65.92 & 20.93 & -91.41 & inactive & & & \\
\hline Z-L-Phe chloromethyl ketone & 26049-94-5 & 8.41 & -123.72 & 12.23 & -156.15 & inactive & & & \\
\hline ZM 39923 hydrochloride & $58753-54-1$ & 2.98 & -105.43 & 15.40 & -145.91 & inactive & & & \\
\hline
\end{tabular}


Fig. 1

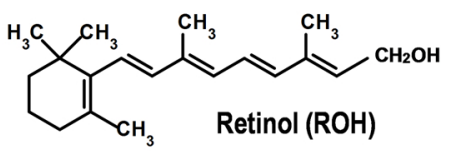<smiles>[R]O[R16]([R1])([R])/C=C/C=C(C)/C=C/C1=C(C)CCCC1(C)C</smiles><smiles>CC1=C(/C=C(C)/C=C/C=C/C(C)=C/C(=O)O)C(C)(C)CCC1</smiles>

Retinol

Retinal

dehydrogenase

dehydrogenase

CYP26s

Retinol

Retinal

Retinoic acid

$$
\begin{gathered}
\text { Retinal } \\
\text { reductase }
\end{gathered}
$$

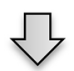

RAR/RXR RARE
Gene transcription 
Fig. 2

A

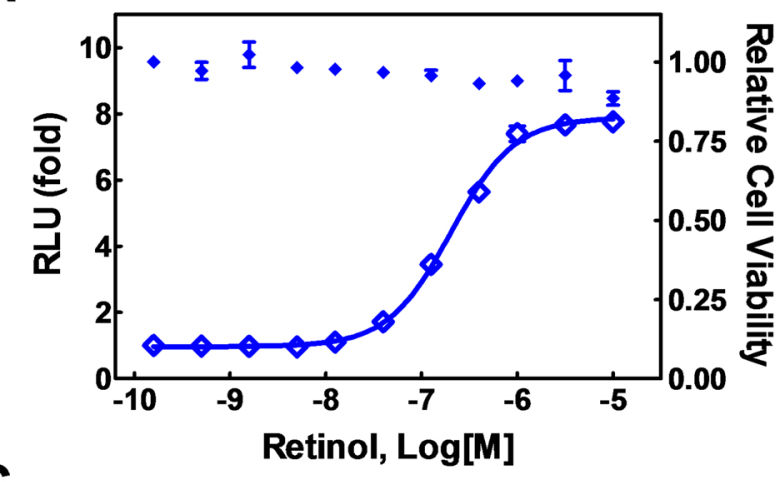

C

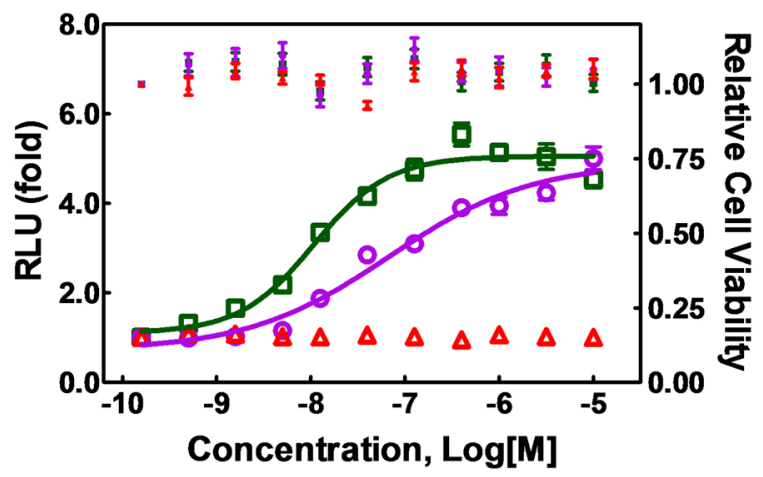

* AM580

- CD437

$\triangle$ SR11237

- Viability-AM580

- Viability-CD437

- Viability-SR11237
B
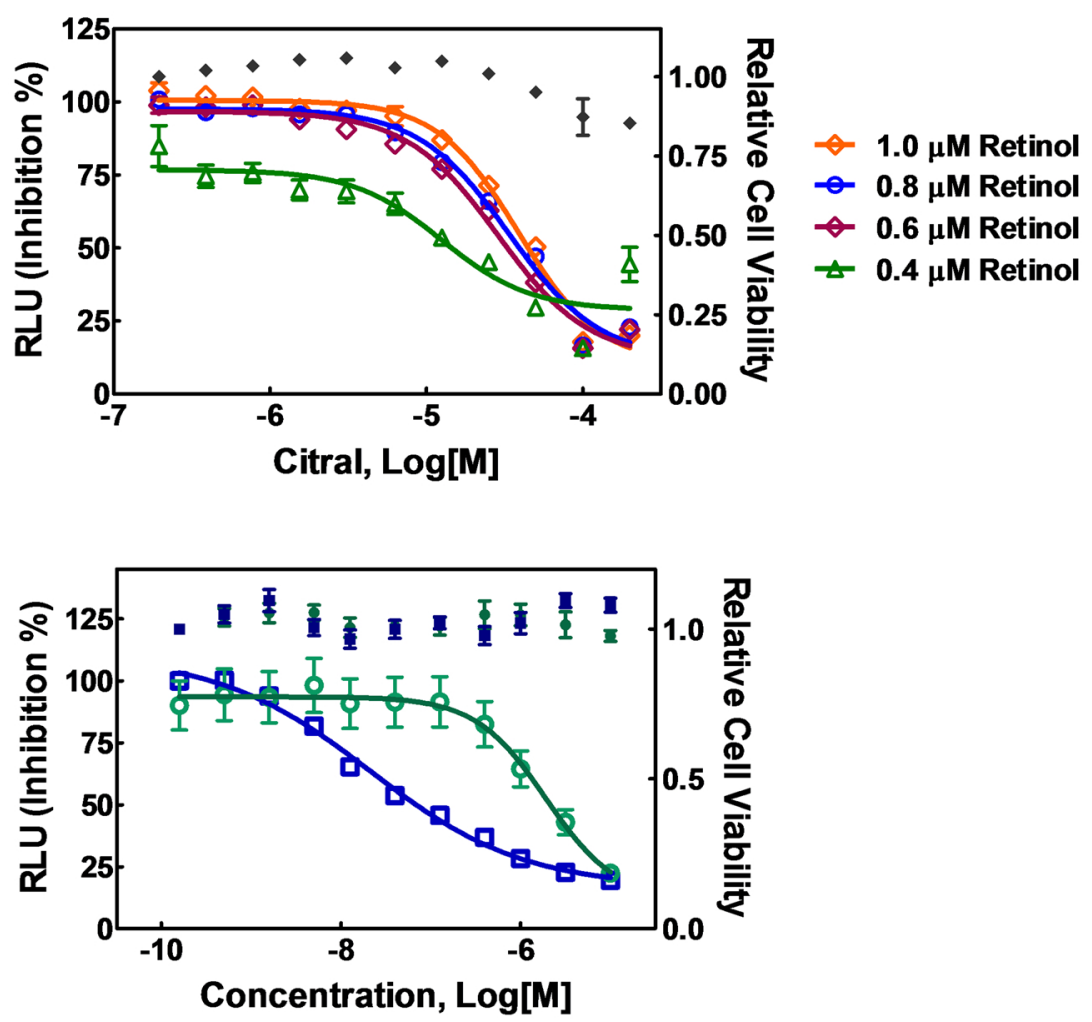

E

\begin{tabular}{cc}
\hline Compound & $\mathrm{EC}_{50} / \mathrm{IC}_{50}$ \\
\hline AM580 & $10.8 \pm 3.5 \mathrm{nM}$ \\
CD437 & $67.8 \pm 35.8 \mathrm{nM}$ \\
SR11237 & $\mathrm{n} / \mathrm{a}$ \\
ER50891 & $21.3 \pm 6.6 \mathrm{nM}$ \\
$\mathrm{HX531}$ & $1.91 \pm 0.5 \mu \mathrm{M}$ \\
\hline
\end{tabular}


Fig. 3

A

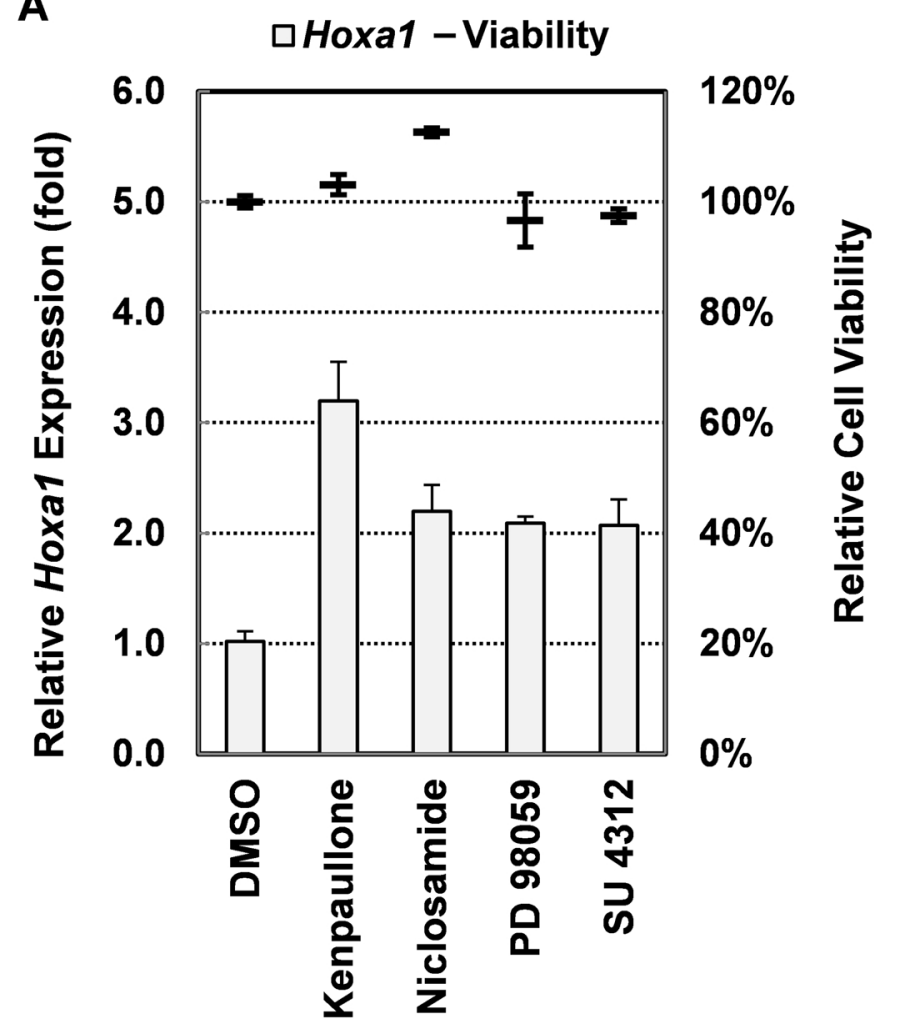

B

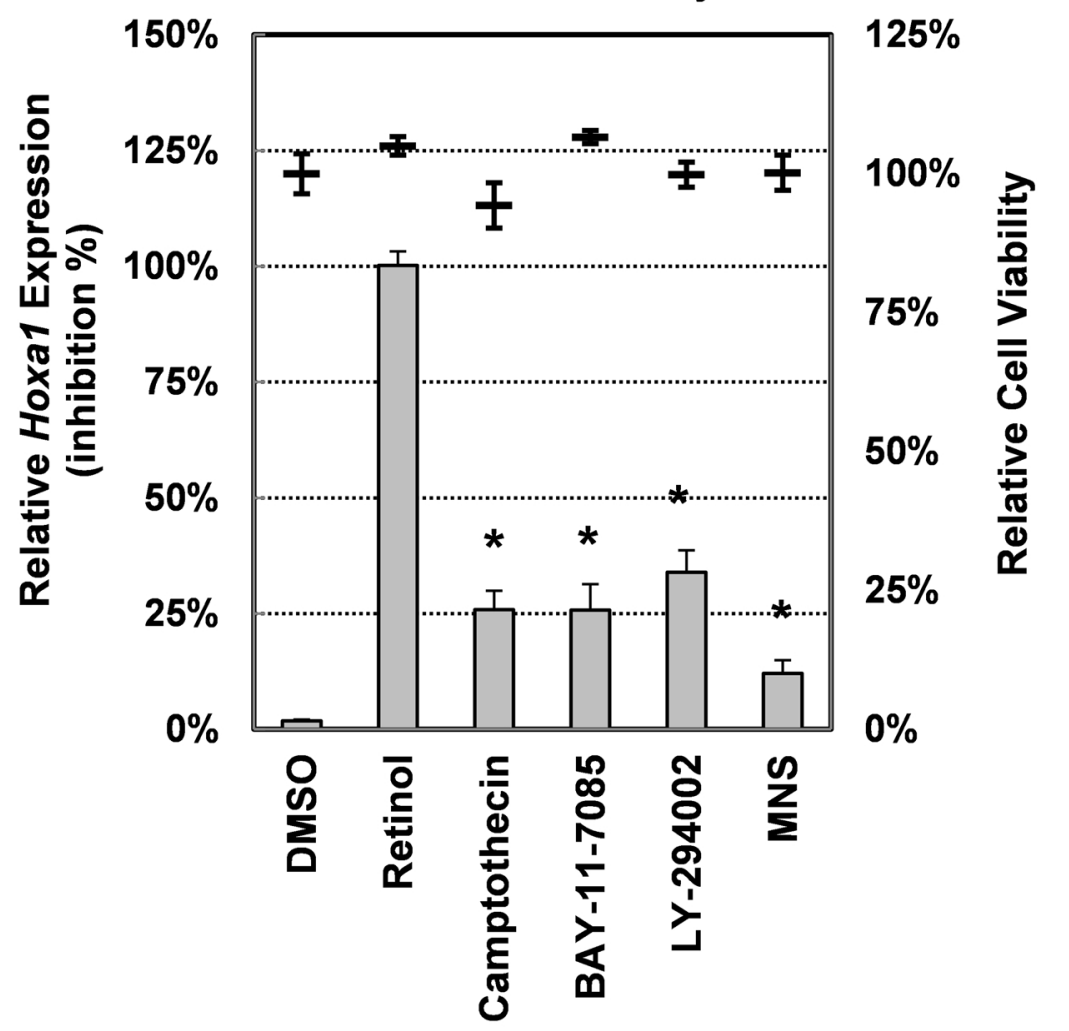


